\title{
Effect of Oryctes rhinoceros larva oil supplementation on serum lipid profile and inflammatory markers in mice fed a cholesterol-based diet
}

\author{
Olarewaju M Oluba $\mathrm{PhD}^{1}$, Sunday J Josiah $\mathrm{PhD}^{2}$, Bamidele S Fagbohunka PhD
}

OM Oluba, SJ Josiah, BS Fagbohunka. Effect of Oryctes rhinoceros larva oil supplementation on serum lipid profile and inflammatory markers in mice fed a cholesterol-based diet. Curr Res Cardiol 2014;2(2):79-83.

A cholesterol-enriched diet has been shown to adversely affect lipoprotein profiles and increase cardiovascular disease risk. Dietary cholesterol plays an important role in modulating inflammatory responses involved in atherosclerosis. In the present study, the effect of Oryctes rhinoceros larva oil $(\mathrm{ORO})$, an unsaturated fatty acid-rich animal fat, on serum lipid profile and some proinflammatory markers in mice fed a cholesterol-based diet (CBD) was investigated. Forty male Swiss albino mice were randomly assigned to four groups consisting of control (normal diet) and three experimental groups fed normal diet supplemented with ORO, CBD only and $\mathrm{CBD}$ supplemented with ORO, respectively. Serum lipid profile,

$\mathrm{H}$ umans and animals have been reported to show consistency in the response of their serum lipid levels to fat-modified diets (1). A significant factor underlying the high continuing incidence of coronary artery disease is a typical diet high in saturated fat and cholesterol, both of which contribute to elevated serum cholesterol levels (2). A serum cholesterol level $>240 \mathrm{mg} / \mathrm{dL}$ ( $>6.216 \mathrm{mmol} / \mathrm{L}$ ) is considered to be high risk and is referred to as hypercholesterolemia (3). Hypercholesterolemia often appears intractable and represents the primary cause of death in patients with the condition. Significant elevation in serum lipid levels, which predisposes to atherosclerosis, is easily monitored using early lipid profiles.

Chronic low-grade inflammation has been shown to be associated with increased risk for cardiovascular and several other chronic degenerative diseases (4). Atherosclerosis, a chronic inflammatory disease, is usually characterized by cholesterol deposition, recruitment and activation of monocytes, macrophages and lymphocytes, and inflammation and fibrosis (5). Interplay among lipid and cholesterol metabolism, cytokines and cellular activity within arterial walls plays a crucial role in atherosclerosis. Interleukin (IL)-1 1 , IL-6, IL-8 and tumour necrosis factor-alpha (TNF- $\alpha$ ) have been reported to affect lipid metabolism and have been implicated in the development of atherosclerotic lessions $(6,7)$. Dietary fats have been shown to play an essential role in modulating immune and inflammatory responses, with both quantity and quality of fats having been shown to affect these processes (8). Findings from some observational studies reveal that dietary intake of very long-chain $\mathrm{n}-3$ polyunsaturated fatty acids $\geq 100 \mathrm{mg} /$ day in Western countries were associated with low concentrations of inflammatory cytokines including C-reactive protein (CRP), IL-6, and intercellular and vascular adhesion molecules $(9,10)$. In addition, alteration in cholesterol levels or metabolism by dietary fat can result in changes to immune and inflammatory responses (8). malondialdehyde, C-reactive protein, interleukin- 6 and tumour necrosis factor-alpha levels were evaluated before and after diet treatment. Serum triacyglycerol, total cholesterol and low-density lipoprotein cholesterol levels were significantly reduced $(\mathrm{P}<0.05)$ in mice fed a CBD diet supplemented with ORO compared with those fed $\mathrm{CBD}$ without ORO. In addition, serum malondialdehyde, C-reactive protein and interleukin-6 levels were significantly lower in mice fed CBD suplemented with $\mathrm{ORO}$ compared with those fed CBD only $(\mathrm{P}<0.05)$. These results suggest that consumption of ORO improved the serum lipid profile and, in addition, may mitigate the attendant adverse inflammatory processes in atherosclerosis.

Key Words: C-reactive protein; Cholesterol-based diet; Interleukin-6; Oil; Oryctes rhinoceros larva; Tumour necrosis factor

In Africa, insect consumption is a traditional and culturally acceptable way by which low-income individuals supplement the meagre protein content of their high-carbohydrate diets. Interest in the use of insects as food has been expressed in several reports (11-13). These insects are usually eaten as part of a meal or a complete meal. Fat is the chief form of energy stored in insect larvae (14). It is usually present in greatest amounts in the mature insect larva before metarmorphosis (15). Some species of insects are eaten as a delicacy in Nigeria, while some are used for traditional medical practice. Among the commonly consumed insect species in Nigeria is Oryctes rhinoceros larva (ORL). A report by Ekpo and Onigbinde (13) showed that ORL contained $38 \%$ (by dry weight) oil with a high degree of unsaturation $(65 \%)$. Although the nutritional potential of ORL oil (ORO) has been reported by several authors, there is very little information regarding the attendant effects of its consumption in vivo on serum lipid profile. The aim of the present study was to evaluate the effect of dietary inclusion of ORO on alteration in serum cholesterol fractions and selected inflammatory markers in mice fed a cholesterol-based diet (CBD).

\section{Chemicals}

\section{METHODS}

All chemicals and solvents used in the present study were Analar grade. Petroleum ether, methanol, cholesterol and thiobarbituric acid were obtained from Sigma Chemical Co (USA). The ELISA kit used for the determination of rat CRP, IL- 6 and TNF- $\alpha$ levels was obtained from RayBiotech, Inc (USA).

\section{ORL}

Live ORL were collected from decaying palm trees, from which sap is tapped as palm wine, at Igoba village near Akure (Nigeria). The ORL were transported to the laboratory in an open plate within $2 \mathrm{~h}$ of collection.

\footnotetext{
${ }^{1}$ Department of Biochemistry, College of Natural Sciences, Joseph Ayo Babalola University, Ikeji Arakeji, Osun State; ${ }^{2}$ Department of Biochemistry, College of Basic Medical Sciences, Igbinedion University, Okada, Edo State; ${ }^{3}$ Department of Biochemistry, College of Basic Medical Sciences, Olabisi Onabanjo University, Ago Iwoye, Ogun State, Nigeria Correspondence: Olarewaju M Oluba, Department of Biochemistry, Collegeof Natural Sciences, Joseph Ayo Babalola University, Ikeji Arakeji, Osun State, Nigeria. E-mail olubamike2000@yahoo.co.uk
} 
TABLE 1

\section{Feed composition}

\begin{tabular}{lcccc}
\hline Composition & Control & ORO & CBD & CBD + ORO \\
\hline Maize flour & 70 & 70 & 70 & 70 \\
Fish meal & 10 & 10 & 10 & 10 \\
Groundnut cake & 20 & 10 & 18 & 08 \\
Cholesterol & - & - & 2 & 2 \\
Oil & - & 10 & - & 10 \\
Total & 100 & 100 & 100 & 100 \\
Calories, Kcal/mol & 500 & 500 & 500 & 500 \\
\hline Values presented as $\%$. & ORO Oryctes rhinocerous oil; CBD Cholesterol- \\
based diet & \multicolumn{5}{l}{}
\end{tabular}

\section{Oil extraction}

Oil was extracted from the ORL using a chloroform methanol (1:2, $\mathrm{v} / \mathrm{v}$ ) mixture as described by Bligh and Dyer (16).

\section{Animals and diets}

A total of 40 male Swiss albino mice (15 g to $22 \mathrm{~g}$ body weight) obtained from the animal laboratory of the Department of Medical Biochemistry, University of Ibadan, Nigeria, were used for the study. The animals were housed in stainless steel cages with raised wired floor at $30^{\circ} \mathrm{C}$ under standard conditions of humidity and a $12 \mathrm{~h}$ light $/ 12 \mathrm{~h}$ dark cycle. They were fed standard feed (Guinea Feeds Ltd, Nigeria) and water ad libitum, and were housed for an initial period of two weeks to acclimatize to their new environment. Subsequently, after an overnight fast, they were weighed and randomly divided into four groups of 10 animals each and placed on a specified diet (control [normal diet], group 1 [ORO], group 2 [CBD] and group 3 [CBD + ORO]) for a period of seven weeks (Table 1). To obtain baseline levels of the evaluated parameters, five animals from each group were euthanized on day zero before commencing the feeding trial. All experimental protocols complied with National Institutes of Health guidelines (17).

\section{Blood collection and serum preparation}

At the end of the feeding experiment, mice in each group were weighed, anesthetized (in a chloroform-saturated chamber) and euthanized by jugular puncture. Blood was collected from the jugular vein into plain, sterile bottles for serum enzyme assays. The blood was allowed to stand for $30 \mathrm{~min}$ to clot and subsequently centrifuged at $3000 \times \mathrm{g}$ for $10 \mathrm{~min}$ at room temperature to separate the serum (18). The serum samples were collected by aspiration using a Pasteur pipette into sterile bijou bottles and stored frozen until required for analysis, which was performed within $72 \mathrm{~h}$.

\section{Lipid profile assays}

Triacylglycerol (TAG) levels were determined according to the enzymatic method using glycerol as standard (Boehringer, Germany). Total cholesterol (TC) was measured by the enzymatic method (CHOD-PAP; Boehringer, Germany) according to the procedure described by Allain et al (19). High-density lipoprotein (HDL) was separated from the serum by precipitation of lipoproteins of lower densities with polyethylene glycol (PEG 20,000, Fluka, Switzerland). After centrifugation, the cholesterol concentration in the HDL fraction, which remained in the supernatant, was determined using the cholesterol CHOD-PAP procedure. Low-density lipoprotein (LDL) was precipitated using heparin at its isoelectric point ( $\mathrm{pH}$ 5.4).

\section{CRP, IL- 6 and TNF- $\alpha$ assays}

CRP, IL- 6 and TNF- $\alpha$ levels were measured using ELISA kits according to the manufacturer's instructions (RayBiotech, Inc, USA), with rat antihuman IL-6 and biotinylated rat antihuman IL-6 monoclonal antibodies (MAbs) or mouse antihuman TNF- $\alpha$ and biotinylated mouse antihuman TNF- $\alpha$ MAbs.

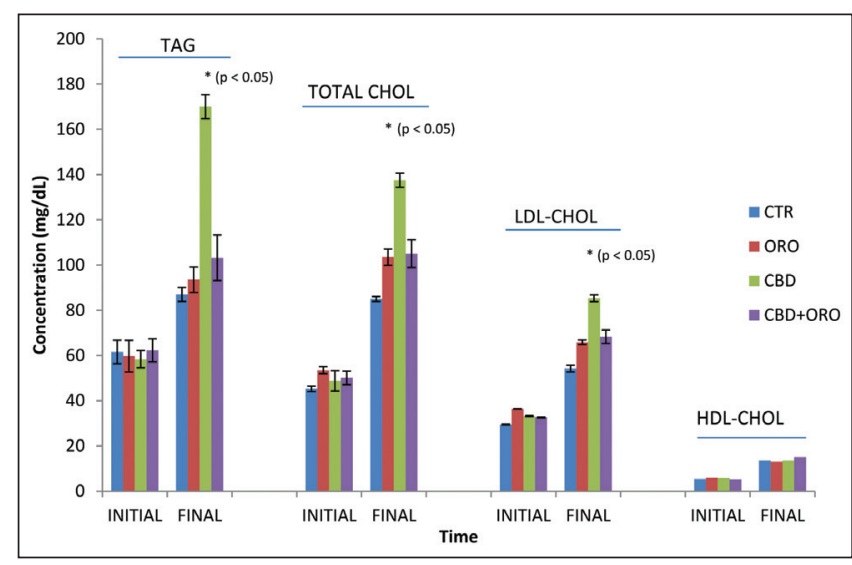

Figure 1) Serum lipid profile of mice fed a cholesterol-based diet (CBD) supplemented with Oryctes rhinocerous larva oil (ORO). Results are presented as means \pm SEM of five independent deteminations. The asterisks indicate parameter values that are significantly different from one another (ie, P<0.05). CHOL Cholesterol; CTR Control; HDL High-density lipoprotein; LDL Low-density lipoprotein

Determination of atherogenic index

The atherogenic index (AI) for each sample was calculated using the formula described Slater and Sawyer (20):

$$
\mathrm{Al}=\mathrm{TC} / \mathrm{HDL} \text {-cholesterol }
$$

\section{Statistical analysis}

Results are presented as means \pm SEM of five independent determinations and analyzed for statistical significance by one-way ANOVA followed by Duncan multiple range test for multiple comparisons. Values were considered to be statistically significant at $\mathrm{P}<0.05$.

\section{RESULTS}

The oil extracted $(21 \% \mathrm{v} / \mathrm{v})$ from ORL was golden yellow in colour and in liquid form at room temperature.

Results obtained for all of the evaluated parameters showed no significant differences $(P>0.05)$ in baseline levels among control and test animals. Weekly feed intake was significantly lower in mice fed the modified diets compared with control (Table 2). No statistically significant difference $(\mathrm{P}<0.05)$ was observed in weekly food intake in mice groups fed a CBD with or without ORO supplement. Observed body weight changes were statistically nonsignificant between mice fed ORO-supplemented diets and those fed the control diet. However, mice fed CBD without ORO supplement showed significantly higher $(\mathrm{P}<0.05)$ body weight values compared with those fed control diet as well as those fed ORO-modified diets.

Lipid profile analysis showed that serum TAG, TC and LDLcholesterol concentrations were not significantly different $(P>0.05)$ in mice fed ORO-modified diets (with or without cholesterol) and those fed the control diet. Mice fed CBD without ORO showed significantly higher $(\mathrm{P}<0.05)$ serum TAG, TC and LDL-cholesterol levels compared with those fed the control diet. Serum HDL-cholesterol was not significantly altered $(\mathrm{P}>0.05)$ between mice fed modified diets and those fed control diet (Figure 1). The AI was significantly higher $(\mathrm{P}<0.05)$ in mice fed the ORO diet and those fed CBD without ORO compared with control (Figure 2). However, the AI value in mice fed CBD supplemented with $\mathrm{ORO}$ and control was not significantly different $(\mathrm{P}>0.05)$.

Serum malondialdehyde (MDA), CRP and IL-6 levels were significantly increased $(\mathrm{P}<0.05)$ in mice fed CBD only, compared with those fed the control diet and those fed ORO (Figures 3 and 4). MDA, CRP and IL-6 concentrations were not significantly different in mice fed CBD supplemented with ORO compared with those fed the control diet. Serum CRP level was significantly higher $(\mathrm{P}<0.05)$ in mice fed the CBD with or without ORO compared with control. However, the 
TABLE 2

Mean weekly feed intake and body weight changes of mice fed a cholesterol-based diet (CBD) supplemented with Oryctes rhinocerous oil (ORO)

\begin{tabular}{|c|c|c|c|c|}
\hline \multirow[b]{2}{*}{ Treatment group } & \multirow[b]{2}{*}{ Weekly feed intake, $g$} & \multicolumn{3}{|c|}{ Body weight, g } \\
\hline & & Final & Initial & Change (\% change) \\
\hline Control & $12.8 \pm 0.53^{\star}$ & $26.4 \pm 1.14^{\dagger}$ & $15.2 \pm 1.4^{\dagger}$ & $11.2 \pm 0.5^{\dagger}(73.7)$ \\
\hline ORO & $10.1 \pm 1.11^{\dagger}$ & $33.7 \pm 0.82^{\star}$ & $21.6 \pm 1.33^{\star}$ & $12.1 \pm 0.12^{\dagger}(56.0)$ \\
\hline CBD & $9.14 \pm 0.32^{\dagger}$ & $33.8 \pm 1.55^{\star}$ & $18.1 \pm 0.18^{\dagger \star}$ & $15.7 \pm 0.33^{\star}(86.7)$ \\
\hline CBD + ORO & $10.3 \pm 0.77^{\dagger}$ & $32.3 \pm 2.13^{*}$ & $20.1 \pm 0.46^{\star}$ & $12.2 \pm 0.11^{\dagger}(60.7)$ \\
\hline
\end{tabular}

Data presented as mean \pm SEM of five independent determinations. Values with different superscripts are significantly different from one another (ie, $P<0.05$ )

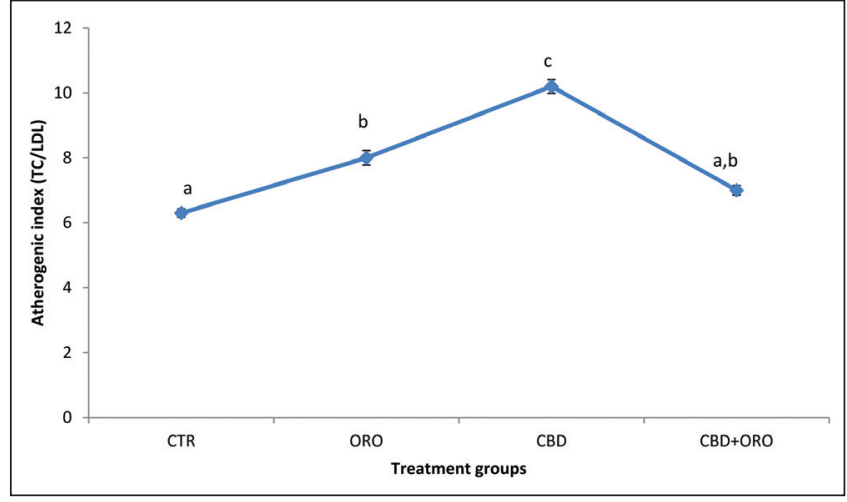

Figure 2) Effect of Oryctes rhinoceros larva oil (ORO) supplementation on atherogenic index in mice fed a cholesterol-based diet (CBD). Results are presented as mean \pm SEM of five independent deteminations. CTR Control; LDL Low-density lipoprotein; TC Total cholesterol

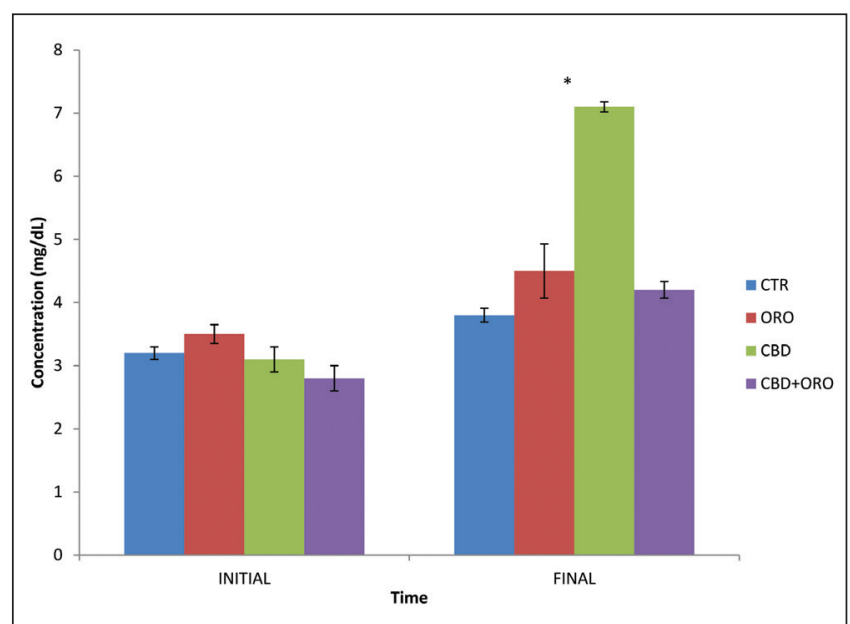

Figure 3) Effect of Oryctes rhinoceros larva oil (ORO) supplementation on malondialdehyde (MDA) levels in mice fed a cholesterol-based diet (CBD). Results are presented as mean \pm SEM of five independent deteminations. CTR Control

CRP level in mice fed CBD supplemented with ORO was significantly lower $(\mathrm{P}<0.05)$ compared with those fed CBD without ORO.

\section{DISCUSSION}

The present study aimed to establish the effect of ORO on serum lipid levels and its attendant effects on proinflammatory markers in mice fed a CBD. Studies have shown that dietary fat intake positively correlates with serum TC values and morbidity from coronary artery disease (21). However, several studies have demonstrated that the fatty acid composition of food is more strongly associated with variations in plasma TC concentration and development of atherosclerosis than the amount of fat consumed $(22,23)$. The general picture is that saturated

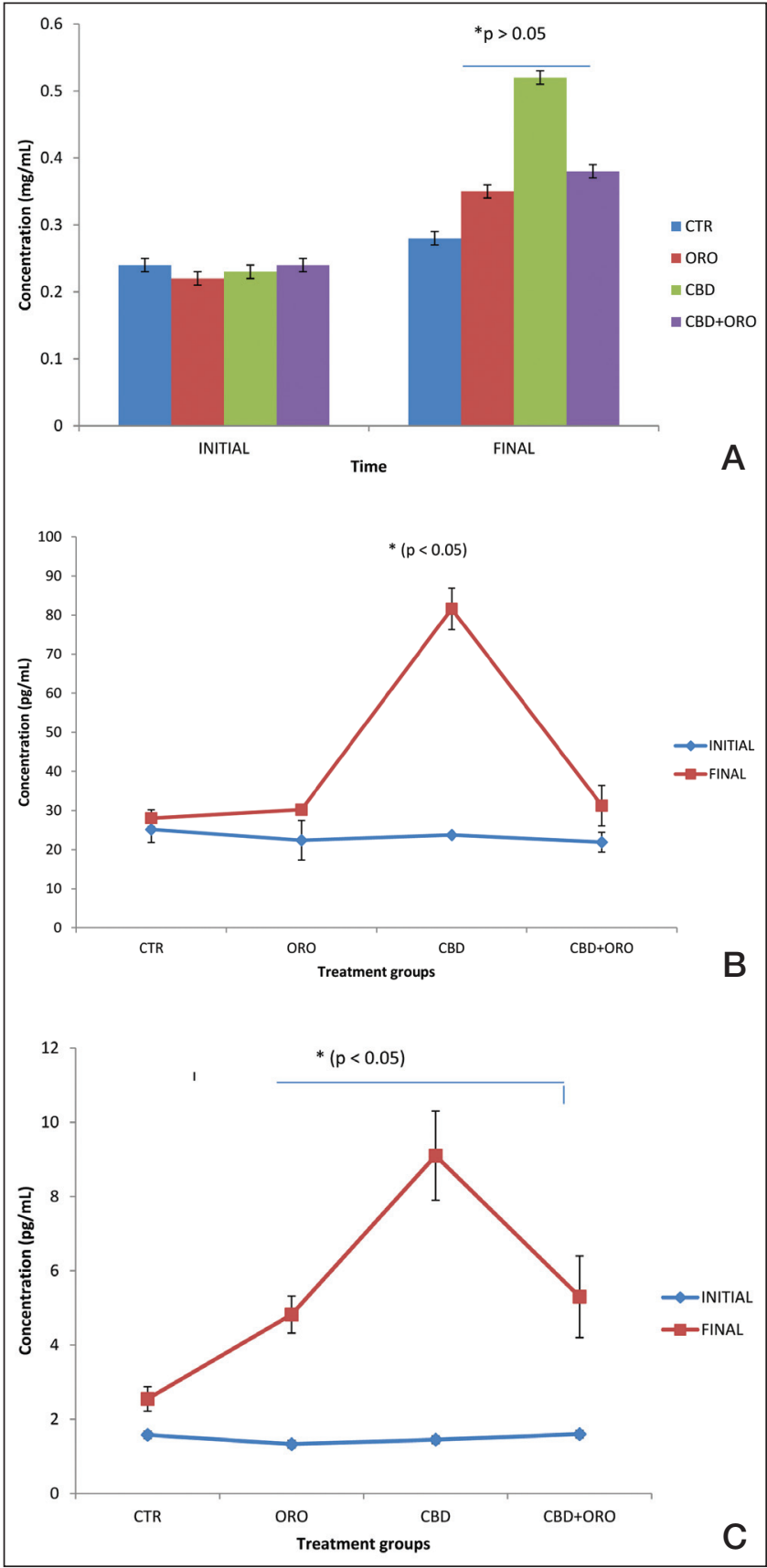

Figure 4) Effect of Oryctes rhinoceros larva oil (ORO) supplementation on serum inflammatory markers in mice fed a cholesterol-based diet (CBD). A C-reactive protein. B Interleukin-6. C Tumour necrosis factor-alpha. Results are presented as mean \pm SEM of five independent deteminations. CTR Control 
fatty acids tend to increase plasma TC level and, thus, increase the risk for coronary artery disease, while unsaturated fatty acids have the opposite effect. A previous study by Ekpo and Onigbinde (24) showed that ORO contains more unsaturated fatty acids than saturated fatty acids. Supporting this fact was that the oil extracted from ORL in the present study and used in feed formulation was in liquid form at room temperature, reflecting its high level of unsaturation. This is surprising because most animal fats are in solid form at room temperature.

Alteration in the concentration of major lipids such as cholesterol, HDL-cholesterol, LDL-cholesterol and TAG can provide useful information regarding lipid metabolism as well as predisposition of the heart to atherosclerosis and its associated coronary artery diseases. TAG, LDLcholesterol and HDL-cholesterol are associated with lipolysis, carriers of plasma cholesterol and atherosclerotic tendency, respectively (25). The reduction in serum TC, TAG and LDL-cholesterol levels observed in mice fed a CBD supplemented with ORO suggests that ORO may not predispose animals to cardiovascular risk. This is supported by the reduction in the computed AI, a useful indicator of cardiovascular disease (26). These results are in agreement with the findings by Scholtz et al (27), in which consumption of ORO lowered serum TC and non-HDLcholesterol concentration compared with coconut oil.

IL-6 is the most important acute-phase protein inducer. In humans, IL-6 strongly stimulates hepatocytes to produce CRP, fibrinogen, haptoglobin and antichymotrypsin (28). IL-6 also acts synergistically with other cytokines, enhancing the proliferation of multipotential hematopoietic progenitors and promotes the maturation of human megakaryocytes (29). IL-6 has been shown to play an important role in atherogenesis (30). In a prospective study by Ridker et al (31), elevated levels of plasma IL- 6 were reported to be associated with increased risk for future myocardial infarction in 404 apparently healthy men during a six-year follow-up period. IL-6 may increase atherothrombotic risk by increasing the release of adhesion molecules by the endothelium, increasing the hepatic release of fibrinogen and having procoagulant effects on platelets (32). IL-6 has also been shown to affect lipid metabolism by inhibiting lipoprotein lipase and stimulating lipolysis (33). In the present study, serum IL-6 level showed a positive correlation with AI and serum TC, LDLcholesterol and CRP concentrations. IL-6 probably stimulates the production of CRP, an acute-phase response protein, which could be a consequence of increased oxidation of LDL-cholesterol in reponse to increased cholesterol deposition in the arterial walls. MDA concentration is a good index of lipid peroxidation. Data obtained from the present study show that serum MDA level positively correlated with serum TC and LDL-cholesterol concentrations, which are components of the membrane with a degree of susceptibility to lipid peroxidation. The significant reduction in serum MDA, CRP and IL-6 levels in mice fed a CBD supplemented with ORO confirms the antioxidative and anti-inflammatory potential of ORO against cholesterol-induced oxidative damage.

Our study is the first to show that consumption of a diet containing ORO improves serum lipid profile and, in addition, represses the production of inflammatory cytokines and acute-phase response protein (ie, $\mathrm{CRP}$ ) in diet-induced hypercholesterolemic mice. This observation is of interest given the various effects of these proinflammatory cytokines on lipid metabolism and inflammatory responses of the vascular system.

\section{CONCLUSION}

The results of the present study suggest that consumption of ORO may help improve serum lipid profile and, in addition, positively mitigate the attendant adverse inflammatory process in atherosclerosis following a high-fat diet, thus improving cardiovascular health.

DISCLOSURES: The authors have no financial disclosures or conflicts of interest to declare.

ACKNOWLEDGEMENTS: The authors acknowledge the support of the following during the extraction and bench work: Leye Babatola, Funke Toyese and Femi Folayemi, all of Joseph Ayo Babalola University, Ikeji Arakeji, Nigeria.

\section{REFERENCES}

1. Oluba OM, Adeyemi O, Ojieh GC, Adebisi KE, Isiosio IO, Aboluwoye CO. Effects of dietary cholesterol on some serum enzymes. J Med Sci 2008;8:390-4.

2. McGill HC. The pathogenesis of atherosclerosis. Clin Chem 1988;34:33-9.

3. Mozaffarian D, Katan MB, Ascherio A, Stampfer MJ, Willet WC. Trans fatty acids and cardiovascular disease. N Engl J Med 2006;354:1601-13.

4. Lloyd-Jones DM, Evans JC, Levy D. Hypertension in adults across the age spectrum: Current outcomes and control in the community. J Am Med Assoc 2005;294:466-72.

5. Ross R. Atherosclerosis: An inflammatory disease. N Engl J Med 1999;340:115-26.

6. Kaul D. Molecular link between cholesterol, cytokines and atherosclerosis. Mol Cell Biochem 2001;219:65-71.

7. Klein RL, Ascencao JL, Mironova M, Haung Y, Lopes-Virella MF. Effect of inflammatory cytokines on the metabolism of low-density lipoproteins by human vascular endothelial cells. Metabolism 2001;50:99-106.

8. Han SN, Leka LS, Lichtenstein AH, Ausman LM, Schaefer EJ, Meydani SN. Effect of hydrogenated and saturated, relative to polyunsaturated, fat on immune and inflammatory responses of adults with moderate hypercholestrolemia. J Lipid Res 2002;43:445-52.

9. Lopez-Garcia E, Schulze MB, Manson JE, et al. Consumption of $(n-3)$ fatty acids is related to plasma biomarkers of inflammation and endothelial activation in women. J Nutr 2004;134:1806-11.

10. Pishon T, Hankinson SE, Hitamisligil GS, Rifai N, Willett WC, Rimm EB. Habitual dietary intake of $n-3$ and $n-6$ fatty acids in relation to inflammatory markers among US men and women. Circulation 2003;108:155-61.

11. Onigbinde AO, Adamolekun B. The nutrient value of Imbrasia belina lepidoptera: Saturnidae (madona). Central Africa J Med 1998;44:125-7.
12. Ekpo KE. Biochemical Investigation of the Nutritional Value and Toxicological Safety of Entomophagy in Southern Nigeria. PhD Thesis, Ambrose Alli University, Ekpoma, Edo State, Nigeria (2003).

13. Ekpo KE, Onigbinde AO. Characterization of lipids in winged reproductives of the termite Macrotermis bellicosus. Pak J Nutr 2007;6:247-51.

14. Chapman RF. The Insects: Structure and Function. London: Hodder and Stoughton Educational, 1980:83-106.

15. Fast PG. Insect lipids. Prog Chem Fats Other Lipids 1970;11:181-242.

16. Bligh EG, Dyer WJ. A Rapid method for total lipid extraction and purification. Can J Biochem Physiol 1959;37:911-7.

17. National Research Council, Guides For the Care and Use of Laboratory Animals, National Institutes of Health, Bethesda, MD, USA, 1985.

18. Onyeneke EC, Alumanah EO, Ononogbu IC. Changes in plasma lecithin: Cholesterol acyl transferase activity in rats fed a cholesterol diet. J Clin Biochem Nutr 1991;10:27-34.

19. Allain CC, Poon LS, Chan CSG, Richmond W, Fu PC. Enzymatic determination of total cholesterol. Clin Chem 1974;20:470-3.

20. Slater TF, Sawyer BC. The stimulatory effects of carbon tetrachloride and other halogenated alkanes on peroxidative reactions in rat liver fractions in vitro. General features of the system used. Biochem J 1971;123:805-14.

21. Kris-Etherton PM, Yu S. Individual fatty acid, effect on plasma lipids and lipoproteins. Human studies. Am J Clin Nutr 1997;65:16285-445.

22. De Lorgeril M, Salem P, Martin JL, Moniaud I, Delaye J, Mamelle N. Mediterranean diet, traditional risk factors, and the rate of cardiovascular complications after myocardial infarction: Final report of the Lyon Diet Heart Study. Circulation 1999;99:779-85.

23. GISSI-Prevenzione Investigators, Dietary supplementation with n-3 polyunsaturated fatty acids and vitamin E after myocardial infarction: Results of the GISSI-Prevenzione trial. Lancet 1999;354:447-55. 
24. Ekpo KE, Onigbinde AO. Nutritional potentials of the larva of Rynchophorus phoenicis (F.). Pak J Nutr 2005;4:289-90.

25. Oyedemi SO, Yakubu MT, Afolayan AJ. Effect of aqueous extract of Leonotis leonorus (L.) leaves in male Wistar rats. Hum Exp Toxicol 2010;29:377-84.

26. Adekunle AS, Oluba A, Babatola LJ, Kamdem JP, Adesokan A. Antiatherogenic, hyperlipidemic and antiinflammatory benefits of black tea and Zanthoxylum zanthoxyloid. Br J Med Med Res 2014;4:1923-37.

27. Scholtz SC, Pieters M, Ooshuizen W, Jerling JC, Bosman MJ, Vorster $\mathrm{HH}$. The effect of red palm olein and refined palm olein on lipids and hemostatic factors in hyperfibrinogaemic subjects. Thromb Res 2004;113:13-25.

28. Weinhold B, Ruther U. Interleukin-6-dependent and independent regulation of the human C-reactive protein gene. Biochem J 1997;327:425-9.
29. Fonseca JE, Santos MJ, Canhao H, Choy E. Interleukin-6 as a key player in systemic inflammation and joint destruction. Autoimmune Rev 2009;8:538-42.

30. Quinn MT, Parthasarathy S, Fong LG, Steinberg D. Oxidatively modified low-density lipoproteins: A potential role in recruitment and retention of monocyte/macrophages during atherosclerosis. Proc Natl Acad Sci USA 1987;84:2995-8.

31. Ridker PM, Rifai N, Stampfer MJ, Hennekens CH. Plasma concentration of interleukin- 6 and the risk of future myocardial infarction among apparently healthy men. Circulation 2000;101:1767-72.

32. Yudkin JS, Kumari M, Humphries SE, Mohamed-Ali V. Inflammation, obesity, stress and coronary heart disease: Is interleukin-6 the link? Atherosclerosis 2000;148:209-14.

33. Van Snick J. Interleukin-6: An overview. Ann Rev Immunol 1990;8:253-78. 